\title{
FACTORS ASSOCIATED WITH UTILIZATION OF HIV COUNSELING SERVICE AT BUDI KEMULIAAN HOSPITAL, BATAM, RIAU
}

\author{
Dawiyah Siregar'), Juanita'), R. Kintoko Rochadi3) \\ 1)Department of Health Policy and Administration, \\ Universitas Sumatera Utara \\ 2)Department of Health Promotion and Behavior, \\ Universitas Sumatera Utara
}

\begin{abstract}
Background: Testing for Human Immunodeficiency Virus (HIV) is the gateway to treatment, care, and prevention. To scale up treatment and prevention, rapid increases in both the volume of testing and the ability to counsel those who are tested are needed. The use of testing globally, however, is very low. Most people living with HIV get testing and counseling only when they already have advanced clinical disease. This study aimed to examine the association between perceived risk of illness and the utilization of HIV counseling service at Budi Kemuliaan Hospital, Batam, Riau.

Subjects and Method: This was a cross-sectional study conducted at Budi Kemuliaan Hospital, Batam, Riau. A sample of 76 patients with HIV was selected for this study. The dependent variable was utilization of HIV counseling service. The independent variables were perceived risk of illness and environment. Data on the use of HIV counseling service were taken from the medical record. The data were collected by questionnaire and analyzed by a multiple logistic regression.

Results: Utilization of HIV counseling was associated with high perceived risk of illness $(\mathrm{OR}=6.63 ; \mathrm{p}=0.001)$, after adjusting for the effect of environmental factor.

Conclusion: Utilization of HIV counseling is associated with high perceived risk of illness, after adjusting for the effect of environmental factor.
\end{abstract}

Keywords: human immunodeficiency virus, counseling, utilization, perceived risk, illness, environment.

\section{Correspondence:}

Dawiyah Siregar. Department of Health Policy and Administration, Universitas Sumatera Utara, Medan, North Sumatera. Email: dawiyah_siregar@yahoo.com. Mobile: 081267500608. 